case, with electric fans off, the ventilation depends just on the natural air flow around the outlet of the venting pipes. The reliability of a passive system is lower and the performance of ventilation is somewhat unpredictable because outdoor air pressure, which is the driving force of providing a negative pressure, is always changing. A merit of a passive system is that it is fully functioning as soon as the building is constructed. It is cost effective since it does not require any energy.

Several materials can be used to block the soil radon gas and reduce the radon concentration of the indoor air. Among them, soil gas mats (SGM) and antiradon membranes (ARM) are widely used, due to easy installation. A SGM and an ARM can effectively protect the indoor air as they function as vapor barriers placed below the slab of the building.
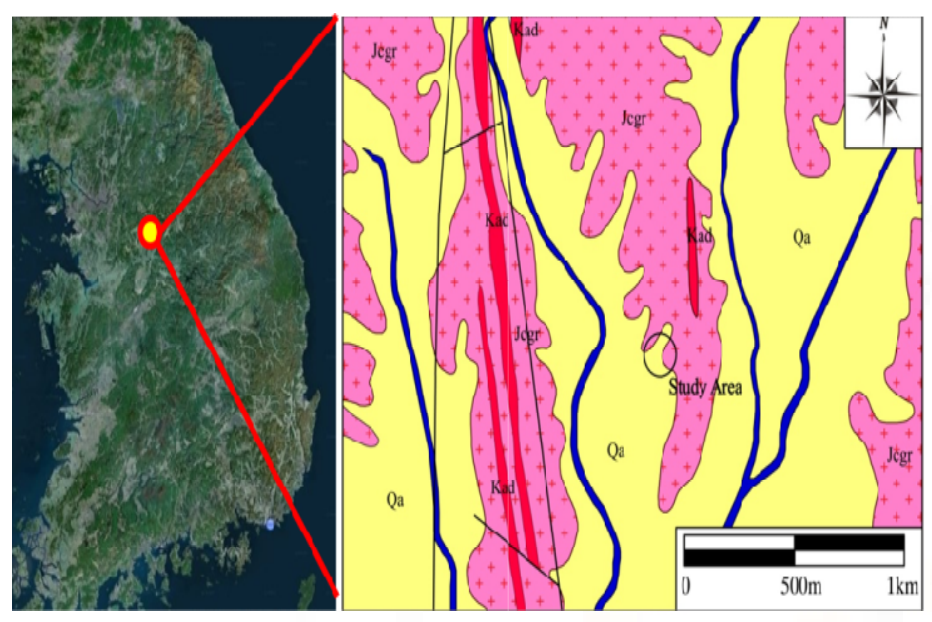

In this paper, we install the test bed for performance evaluation of radon reduction of a SGM and an ARM. The test bed was set in a concrete structure which consists of eight partitioned rooms. The bottom side of each room is covered by radon gas soil sampled at nearby open fields. Then, we install SGMs and ARMs on top of the soil to protect the indoor air.

\section{Test Bed Installation for Evaluation of Radon Mitigating Materials}

The test location is at $80 \mathrm{~km}$ southeast of Seoul, the capital city of South Korea. The geographic coordinates are N36.9603262 and E127.4676599, as shown in Fig. 1. The soil components are coarse granite and quaternary alluvium. The temperature range was from $14^{\circ} \mathrm{C}$ to $29^{\circ} \mathrm{C}$ in August, 2016, which is the test period.

The radon concentration of indoor air of test rooms was measured by an E-perm electret monitor. During the exposure period, the charges in the electrets in an E-perm chamber continue to deplete with the negative ions generated from decaying of radon particles in the atmosphere. The decrease of charges is measured by reading the electric voltage of the electrets before and after the exposure ${ }^{(17)}$. The voltage difference corresponds to the radon concentration of the atmosphere. We used an S-type (short-term) E-perm electret radon monitor (Rad Elec Inc., USA), which is designed for short-term tests of 48 hours to 10 days (18)

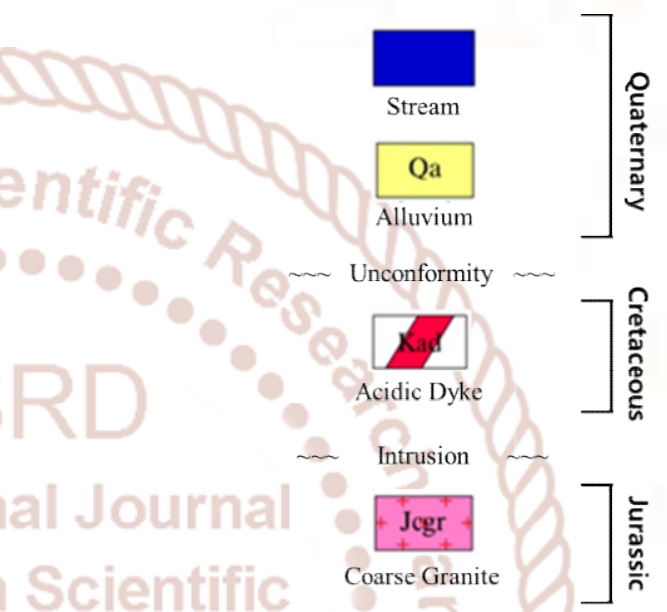

Figure 1: The location and geological formations of the study area

When a house is built on slab-on-grade or basement foundation, the radon gas should be able to move laterally beneath the slab to the location where the vent pipe collects the radon gas. A SGM helps to collect soil gas collection beneath slabs. A SGM consists of interconnected strips of drainage mats which are laid on top of the soil sub-grade and beneath the slab. Drain mats are made of plastic material of sufficient permeability beneath concrete floors to allow for the capture and exhaust of naturally occurring radon gas. Usually, SGMs are installed in a form of a loop of matting inside the exterior perimeter foundation walls.

An ARM protects the building from the ingress of radon gas into the property. ARMs are made of polymer films of low permeability which can prevent the ingress of radon gas from entering into the interior of buildings. Covering the entire footprint of the floor area, it provides a sealing between the gas permeable layer and the concrete slab. The sheeting can act as a vapor barrier to reduce moisture and other soil gas entry into the home. 


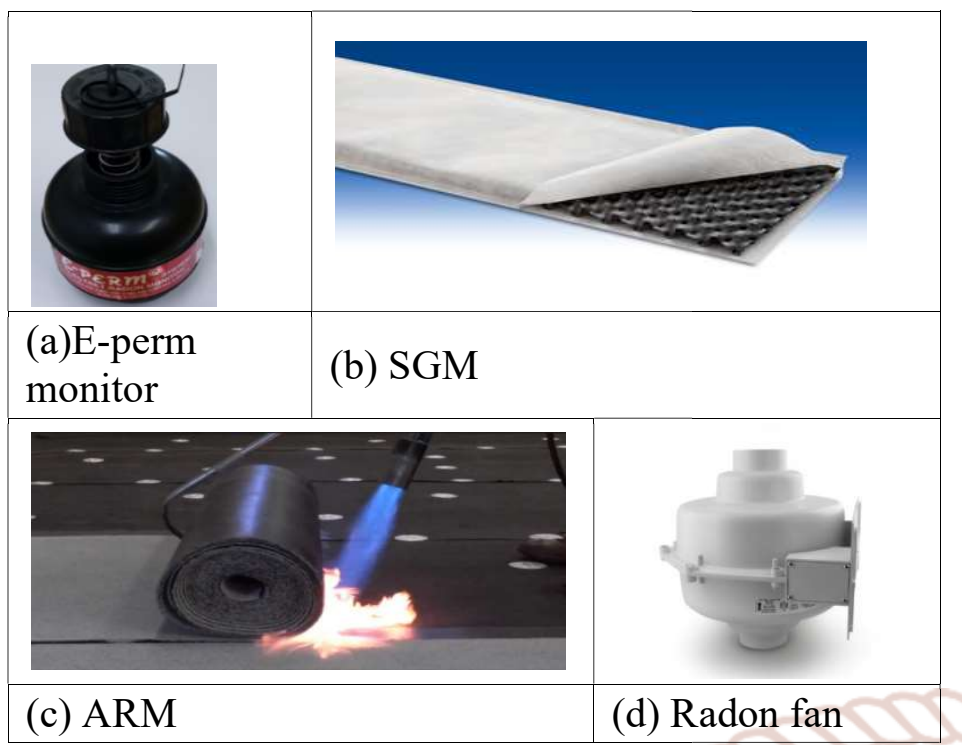

Figure 2: Radon measuring device and radon mitigating materials

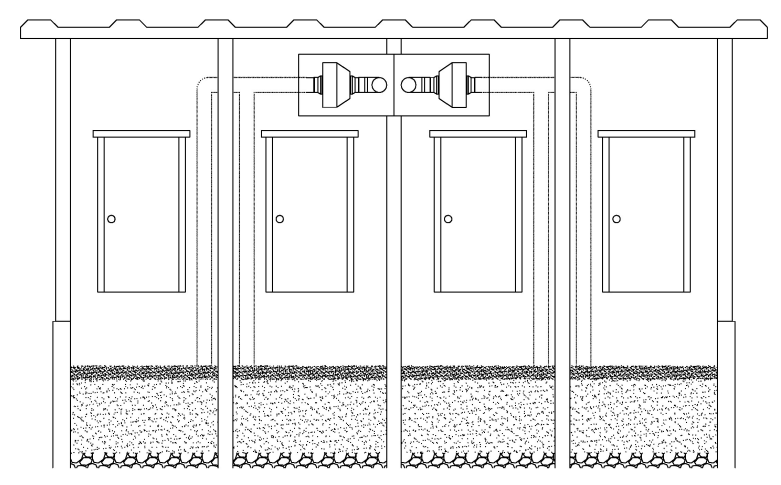

(a) Front view

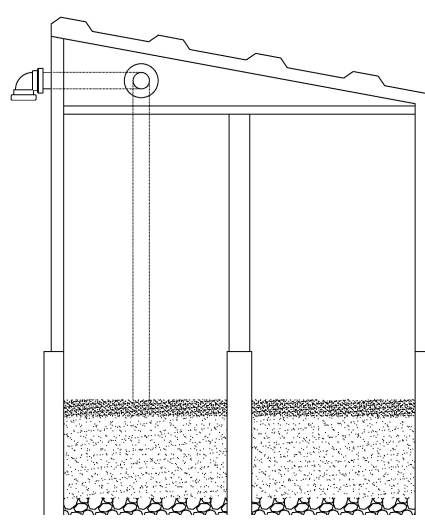

(b) Side view

Figure 3: The architectural drawing of a model house

The model number of the electric ventilation fan used in this study is GP501, manufactured by RadonAway, USA.

The images of the E-perm monitor, SGM, ARM and the electric ventilation fan are shown in Fig. 2(a) through Fig. 2(d). The layout of the installation of radon mitigating materials in each of the eight rooms is shown in Fig. 3.
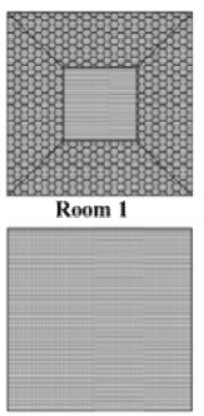

Room 5
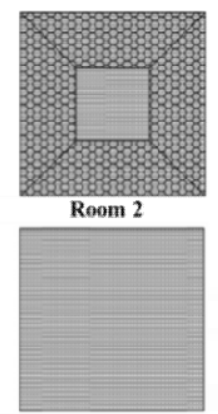

Room 6

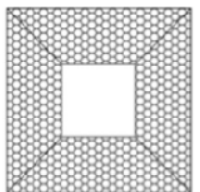

Room 3

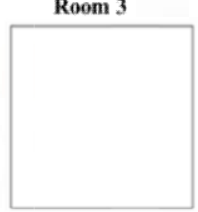

Room 7

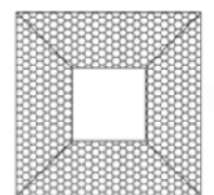

Room 4

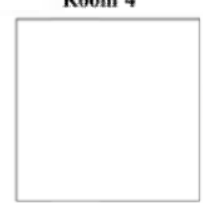

Room 8
Installation examples of radonn mitigating materials

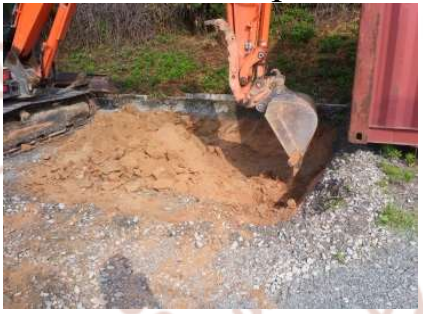

(a) Excavation work

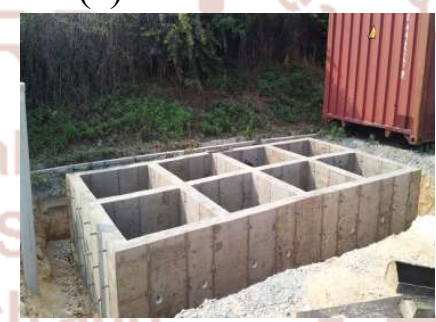

(c) Removal of molding

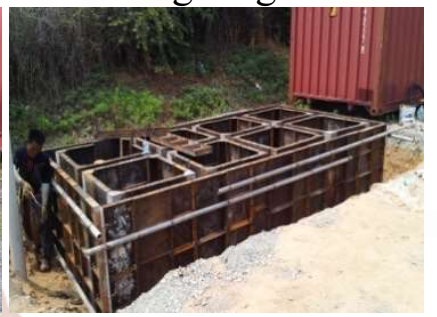

(b) Molding

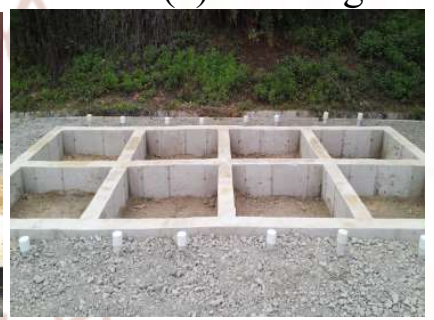

(d) Covering up with soil

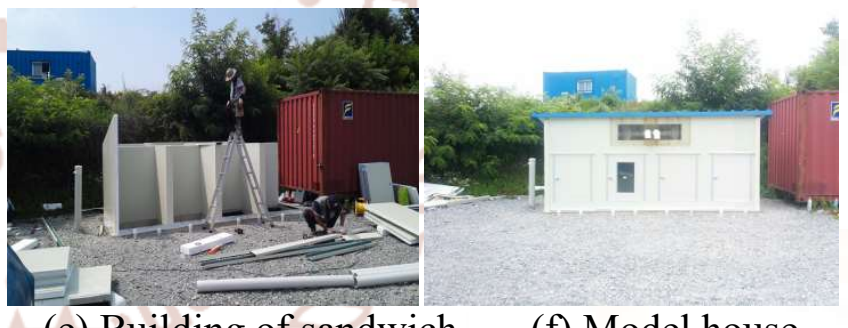
(e) Building of sandwich panel
(f) Model house completion

In order to evaluate the performance of radon mitigating materials such as a SGM, an ARM and a radon fan, a model house was constructed. It is located at the study area shown in Fig. 1. The radon concentration of the soil gas in the model house and the surrounding area was $58.49 \mathrm{kBq} / \mathrm{m}^{3}$. The radon concentration was measured using RAD7 after digging into the ground with a depth of $70 \mathrm{~cm}$. The model house consists of eight separate rooms whose dimensions are $1 \mathrm{~m}$ long, $1 \mathrm{~m}$ wide and $2 \mathrm{~m}$ high (Fig. $3)$. The dimension of the substructure of each room is $1 \mathrm{~m}$ long, $1 \mathrm{~m}$ wide and $0.7 \mathrm{~m}$ high. The substructure consists of three layers. The lowest one was covered with pebbles. The middle one was for sample soil. 
The radon mitigating materials were installed on the top of the substructure. Walls, doors, ceilings and roofs were made of sandwich panels. All of the joints were sealed tightly.

In room 1 and in room 2, SGMs, ARMs and a radon fan are installed. P-1 is label for the case with the radon fan off and A-1 is the label for the case with the radon fan on. In room 3 and in room 4, SGMs and a radon fan are installed. P-2 is the label for case with the radon fan off and A-2 is the label for the case with the radon fan on. In room 5 and in room 6, ARMs are installed and the label is P-3. In room 7 and in room 8, no radon mitigating materials are installed and the label is 'Unprotected'. Each radon mitigating material is installed in two rooms so that we can reduce the interference between rooms and the deviation of concentration due to the difference of sample quantities. For this test, a model house was built as shown in Fig. 5, based on the design layout in Fig. 3.

\section{Concluding Remarks}

Radon is an invisible, odorless and chemically inactive radioactive gas that is produced by the decay of uranium ore, such as radium, actinium, or thorium. Because inhaling radon and its radioactive decay products causes irradiation of lung tissue, prolonged exposure to high concentrations of radon significantly increases the risk of developing cancer. It has been reported that the US. Environmental Protection Agency estimates exposure to naturally occurring radon leads to 21,000 lung cancer deaths nationwide each year, making radon the nation's primary environmental health threat and second only to cigarette smoking as a cause of fatal lung cancer. In this paper, we install the test bed for performance evaluation of radon reduction of a SGM and an ARM. The test bed was set in a concrete structure which consists of eight partitioned rooms. The bottom side of each room is covered by radon gas soil sampled at nearby open fields. Then, we install SGMs and ARMs on top of the soil to protect the indoor air.

\section{Acknowledgment}

This work was also supported by the National Research Foundation of Korea (NRF) grant funded by the Korea government (MSIP) (No. 2016011249).

\section{REFERENCES}

1. Minkin L and Shapovalov AS, "Indoor radon entry: 30 years later," Iran J Radiat Res, Vol.6, No.1, pp. 1-6, 2008.

2. Abel-Ghany HA, "Exposure of school children to alpha particles," Iran J Radiat Res, Vol.6, No.3, pp.113-120, 2008

3. Bouzarjomehri F and Ehrampoosh NH, "Radon level in dwellings basement of Yazd-Iran," Iran J Radiat Res, Vol.6, No.3, pp.141-144, 2008

4. Sathish LA, Nagaraja K, Ramanna HC, Nagesh V, Sundareshan S, "Concentration of radon, thoron and their progeny levels in different types of floorings, walls, rooms and building materials," Iran J Radiat Res, Vol.7, No.1, pp.1-9, 2009

5. Hadad K, Hakimdavoud MR, Hashemi-Tilehnoee M, "Indoor radon survey in Shiraz-Iran using developed passive measurement method," Iran $J$ Radiat Res, Vol.9, No.3, pp.175-182, 2011

6. Verma D, Shakir Khan M, Zubair M, "Measurements of indoor radon, thoron and their progeny in Farrukhabad city of Uttar Pradesh, India," Iran J Radiat Res, Vol.10, No.3-4, pp.193196, 2012

7. Leghrouz AA, Abu-Samreh MM, Shehadeh AK, "Measurements of indoor radon concentration levels in dwellings in Bethlehem, Palestine," Health Physics, Vol.104, No.2, pp.163-167, 2013

8. Barros NG, Steck DJ, Field RW, "A comparison of winter short-term and annual average radon measurements in basements of a radon-prone region and evaluation of further radon testing indicators," Health Physics, Vol.106, No.5, pp.535-544, 2014

9. Al-zabadi H, Mallah K, Saffarini G, "Indoor exposure assessment of radon in the elementary schools, Palestine," International Journal of Radiation Research, Vol.13, No.3, pp.221-228, 2015

10. Fahiminia M, Fouladi-Fard R, Ardani R, Naddafi $\mathrm{K}$, Hassanvand MS, Mohammadbeigi A, "Indoor radon measurements in residential dwellings in Qom, Iran," International Journal of Radiation Research, Vol.14, No.4, pp.331-339, 2016

11. Alqadi MK, Alzoubi FY, Jaber MA, “Assessment of radon gas using passive dosimeter in Amman and Al-Rusaifa cities, Jordan," International Journal of Radiation Research, Vol.14, No.4, pp.367-371, 2016

12. Vaupotič J, Smrekar N, Žunić ZS, “Comparison of radon doses based on different radon monitoring 


\section{approaches," Journal of Environmental}

Radioactivity, Vol.169-170, pp.19-26, 2017

13. Je H, Kang C, Chon H, "Indoor radon levels in the room of Kwanak Campus, Seoul National University," Econ. Environ. Geol. (in Korean), Vol.31, No.5, pp.425-430, 1998

14. Kim C, Lee S, Lee D, Chang B, Rho B, Kang H, "Nationwide survey of radon levels in Korea," Health Physics, Vol.84, No.3, pp.354-360, 2003

15. Kim Y, Chang B, Park H, Kim C, Tokonami S, "National radon survey in Korea," Radiation Protection Dosimetry, Vol.146, No.1-3, pp.6-10, 2011

16. Lee C, Kwon M, Kang D, Park T, Park S, Kwak J, "Distribution of radon concentrations in child-care facilities in South Korea," Journal of Environmental Radioactivity, Vol.167, pp.80-85, 2017

17. http://www.biomation.com/radon/eperm.htm

18. http://www.osha.gov/dts/sltc/methods/inorganic/id 208/id208.pdf

19. https://www.epa.gov/radon/building-radon-outstep-step-guide-how-build-radon-resistant-homes 